\title{
Neurenteric Cysts of the Spinal Cord Mimicking Multiple Sclerosis
}

\author{
H.V. VINTERS, and J.J. GILBERT
}

SUMMARY: A 54-year-old man died following a 20-year course of intermittent neurologic symproms. He carried a diagnosis of multiple sclerosis, with most severe involvement thought to be in the spinal cord. At autopsy, two neurenteric (enterogenous) cysts were found to indent the anterior spinal cord - at the T4 and TII cord levels. Partial diplomyelia was present in the lumbo-sacral cord. These findings represent a unique combination of congenital abnormalities. Their embryogenesis and pathogenesis are discussed.

RESUMÉ: Un homme de 54 ans est décédé à la suite de l'évolution de 20 ans de symptômes neurologiques intermittents. On lui avait donné un diagnostic de sclérose-en-plaques à prodominance dans la moëlle épinière. A l'autopsie on trouva deux kystes entérogènes (neurentériques) qui indentaient la moëlle spinale antérieure aux niveaux D4 et DII. Dans la moëlle lombo-sacrée il y avait une diplomvélie partielle. Ces données forment une combinaison de malformations congénitales inédite. Nous en discutons l'embryogénèse et la pathogénèse.

From the Departments of Pathology and Clinical Neurological Sciences, Victoria Hospital Corporation. and The University of Western Ontario, London, Ontario.

Reprint requests: Dr. J.J. Gilbert, Victoria Hospital Corporation, 375 South Street, London, Ontario. Canada N6A $4 G 5$.

\section{INTRODUCTION}

Neurenteric cysts are a rare cause of intradural extramedullary compression of the spinal cord. They are believed to represent a developmental anomaly, and have been described by a number of other names, including archenteric, endodermal, enterogenous, teratomatous or teratoid cysts, and gastrocystoma.

\section{CASE REPORT}

A 54-year-old man died following a 20year history of intermittent neurologic disturbance. At age 35 years, while lifting a heavy weight, he experienced the sudden onset of low back pain and within 15 minutes was unable to walk. The clinical diagnosis was 'disc protrusion' and he was treated with bed rest. Despite overall improvement, he noted transient numbness and discomfort in the left knee, anteromedial aspect of the left thigh, and left foot. Two years later, he experienced an episode of left foot weakness which resolved spontaneously. His only other complaint was of occasional dribbling of urine. Complete neurological assessment at the age of 39 years revealed only an ill-defined sensory impairment over the left leg and thigh, and a mild asymmetry of knee jerks. Lumbo-sacral spine radiographs showed 'minor developmental abnormalities in the arches and pedicles of L4 and L5 on the right', but these were not further detailed.

One year later the patient noted gradually increasing weakness of the left leg over 3 weeks, associated with stiffness and clumsiness of the right leg, and urinary urgency. Neurologic examination revealed increased tone and weakness in the left leg, with hyperreflexia and an upgoing left toe. A complete myelogram was normal, and CSF examination showed a protein of 29 $\mathrm{mgm} / \mathrm{dl}$, with 3 cells per $\mathrm{cu}$. $\mathrm{mm}$.

Over the ensuing 5 years, he experienced intermittent weak ness of the lower extremities, with bladder and bowel disturbance. The clinical diagnosis was multiple sclerosis. Nevertheless, he was said to be walking until 10 days prior to his final hospital admission in February 1979. Neurologic examination at this time revealed decreased power with increased tone in the left toe. and diminished perception of all sensory modalities in the left leg, with minimal weakness in the right leg and bilaterally upgoing toes. He died soon after admission with widely disseminated carcinoma of the lung.

At autopsy, there was widespread poorly differentiated carcinoma of the lung. No intestinal abnormalities were present and a thoracic or mediastinal cyst was not seen. Examination of the central nervous system revealed multiple cerebral metastases from the lung tumor. There were no demyelinating plaques. The anterior surface of the spinal cord was indented at the T4 and TII cord levels by two separate oval cysts in the subarachnoid space, and tightly adherent to the spinal cord (Fig. 1). The larger of these, at T11, measured $1.2 \mathrm{~cm}$. in diameter, and had distorted and virtually replaced all normal spinal cord tissue at this level (Fig. 2). Both cysts contained a viscous, cloudy white liquid. The wall of each cyst was composed of an epithelium which varied from flattened to cuboidal and in some areas was of the pseudostratified columnar variety (Fig. 3). The epithelium was seen to rest on a basement membrane, underlying which was a thin layer of connective tissue. In places, the epithelium was ciliated, and in others the cells had a PAS (periodic acid-Schiff) positive cytoplasm. The material within the cyst cavity was PAS positive. There was secondary degeneration of the dorsal columns rostral to the larger cyst, and corticospinal tract degeneration caudad to it. There was mild Schwannosis in the remaining spinal cord parenchyma dorsal to the cyst in the low thoracic region. In the lumbo-sacral cord, a partial diplomyelia was seen (Fig. 4). No abnormalities of the vertebral column were detected.

\section{DISCUSSION}

The interest in neurenteric cysts of the spinal cord is reflected by the lively debate in the literature as to their embryogenesis and pathogenesis. Some authors (Hoefnagel et al., 1962; Rewcastle and Francoeur, 1964; 


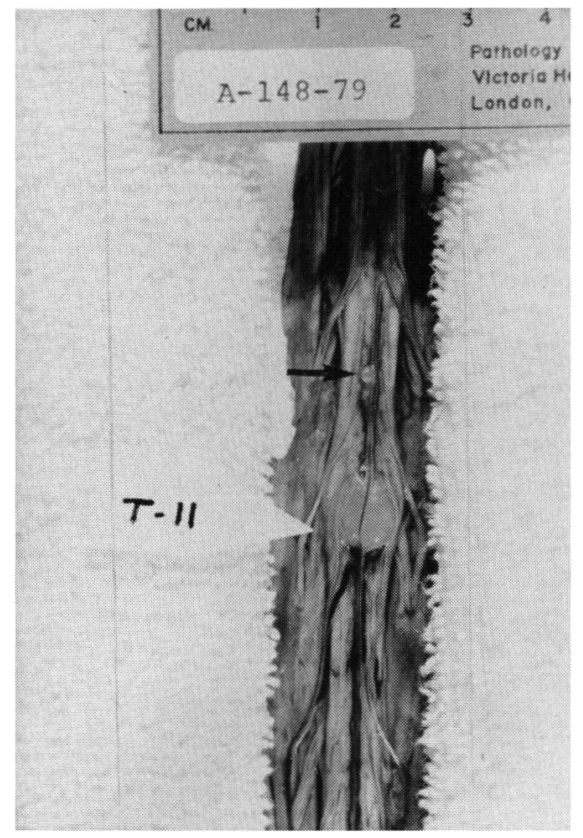

Figure 1 - Anterior aspect of the spinal cord, showing a cyst at the TIl level. The anterior spinal artery passes over this lesion. A much smaller third cyst (arrow) is seen immediately above the cyst at TII.

Rosenbaum et al., 1978) believe that a cyst with the morphology described in the present case - i.e. a cyst wall that lacks submucosa or muscularis should properly be called a teratomatous cyst, and support their argument with 'sex' chromatin studies of the epithelial and connective tissue lining; nuclei of some cyst cells from male patients contained female sex chromatin bodies. Others accept the view that these lesions, even lacking the other normal layers of alimentary tract lining, constitute a developmental anomaly which has its origins early in embryonic development (Dorsey and Tabrisky, 1966; Harriman, 1958; Levin and Antin, 1964; Scoville et 'al., 1963). Theories of embryogenesis among the latter groups, though they differ from author to author in specifics, agree on some type of abnormal adhesion between entoderm, neuroectoderm, and notochordal elements at two to three weeks of embryonic life. This may then lead in later life to an isolated neurenteric cyst compressing the cord, or a spectrum of congenital anomalies, mediastinal cysts (also lined by gastrointestinal epithelium), and alimentary tract duplication (Millis and Holmes, 1973; Rhaney and Barclay, 1959; Silvernail and Brown, 1972).

A recent review of spinal endodermal cysts (Palma and Di Lorenzo, 1976), most with histology virtually identical to that in our case, has stressed several significant clinical features: namely, that in the absence of other associated congenital abnormalities, these cystic lesions may become manifest quite late in life; they may present with symptoms that wax and wane over weeks to months; and the prognosis for neurologic recovery following decompression of the spinal cord is good. Further, the review of the literature has revealed that neurenteric cysts without associated congenital anomalies are usually found in the cervical region, often present clinically in the third and fourth decades, and occur more frequently in males than females, by a ratio of $2: 1$.

More recent cases that have been reported emphasize the frequent association between neurenteric cysts and vertebral anomalies, with or without the presence of mediastinal cysts (Laha and Huestis, 1975; Odake et al., 1976; Page, 1974). Occasionally, the spinal cyst has even shown to communicate directly with a mediastinal cyst through an anterior spina bifida (Piramoon and Abbassioun, 1974). The patients described are all younger than the one in the present case, and most are in the pediatric age group.

A most unusual condition has also been described (Pilz et al., 1977) in which an enterogenous cyst was associated with 'mucilage filled clefts' of the cervical and thoracic spinal cord (mucomyelia). Bale (1973) has reported a 4-month-old infant who had, in addition to a gastro-enterogenous cyst of the thoracic cord, vertebral anomalies and diastematomyelia in the thoracic and lumbar regions of the cord.

Other papers have stressed, however,

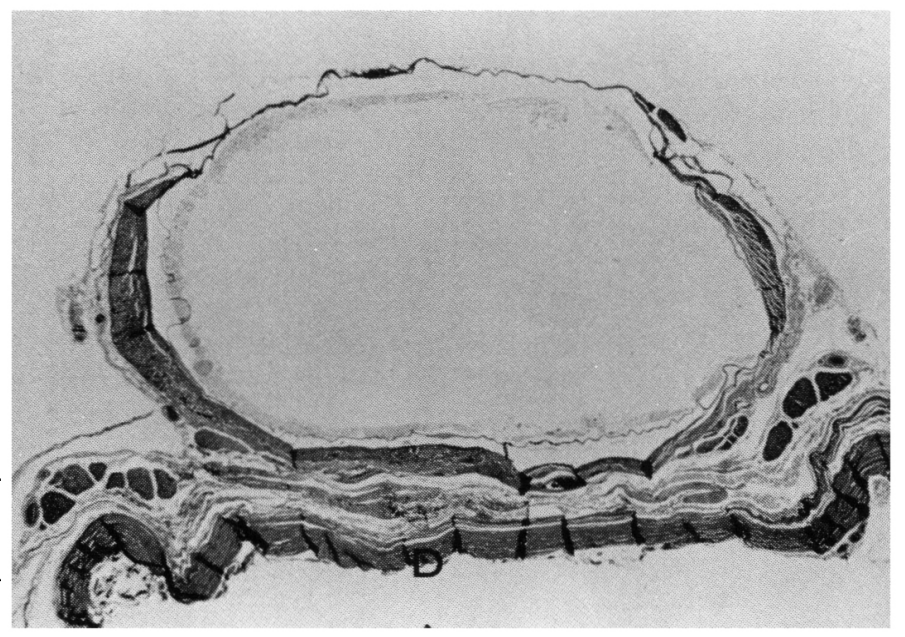

Figure 2 - Cross-section of the spinal cord at T11, showing a large cyst displacing the normal cord tissue. The posterior surface is facing down. D - dura. (H \& E; x 14).

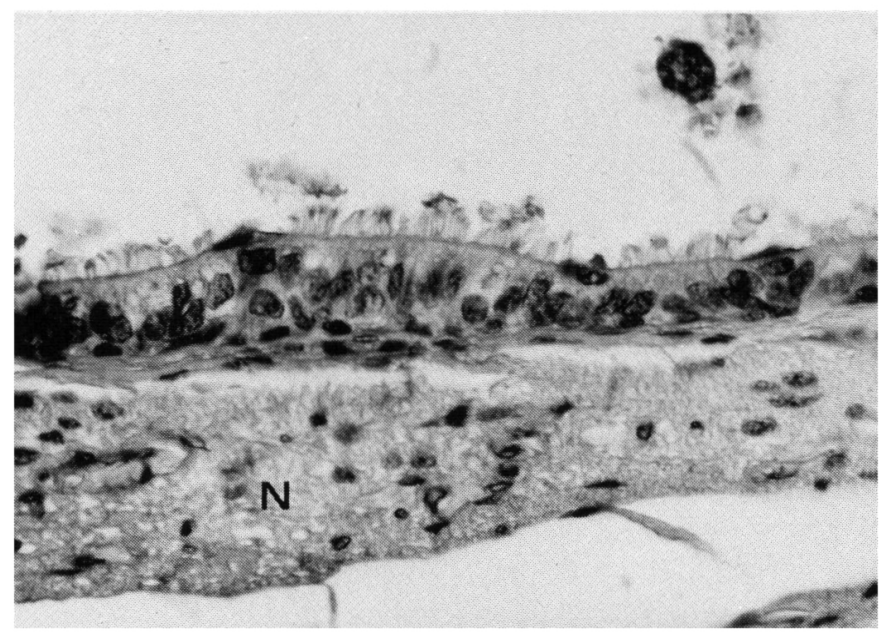

Figure 3 - A portion of the cyst wall shows ciliated pseudost ratified columnar epithelium lying on a basement membrane and a thin layer of connective tissue. A small amount of neuroglial tissue (N) remains deep to the cyst wall ( $\mathrm{H} \& \mathrm{E}$; original mag. $\mathrm{x}$ 500). 


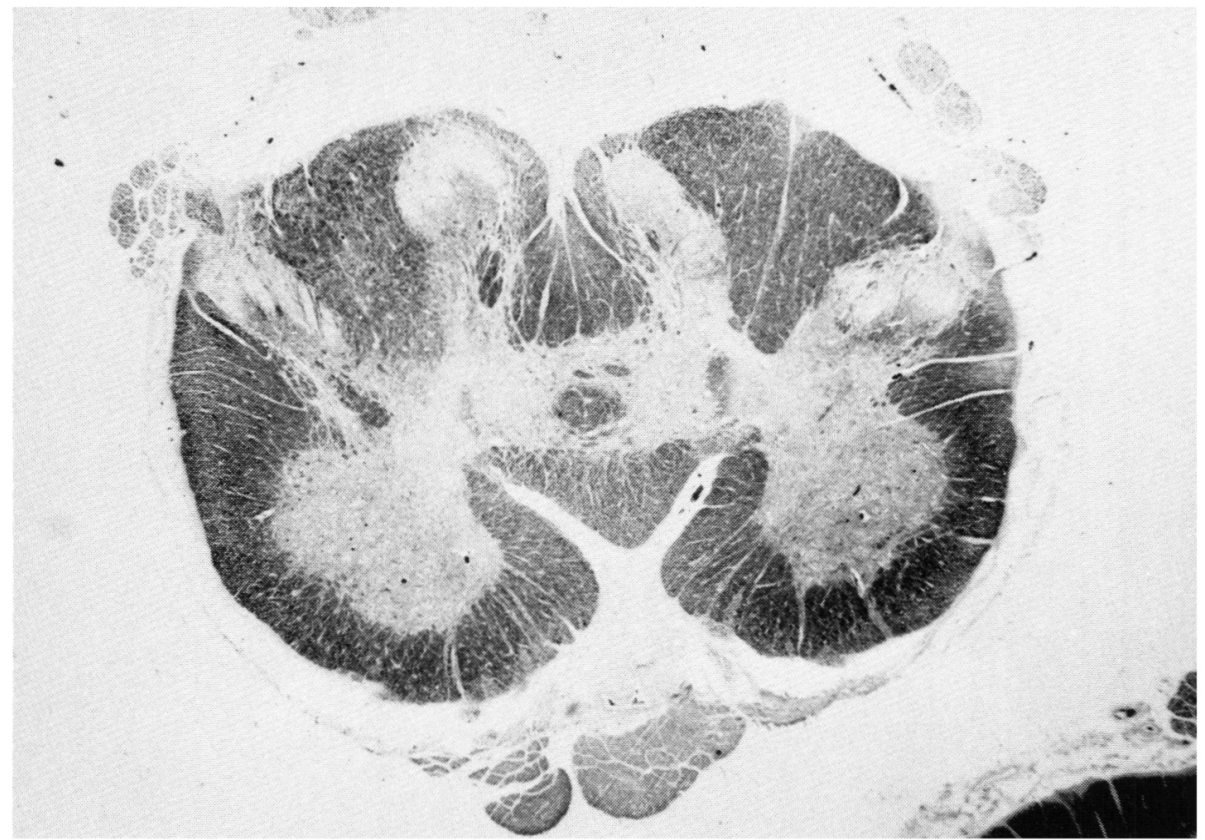

Figure 4 - A partial diplomyelia is present in the lumbar spinal cord. Four dorsal gray horns are present. There is partial fusion of the medial ventral gray horns (Solochrome $\mathrm{R} ; \mathrm{x}$ 14).

that these cystic lesions may be an entirely isolated pathologic finding (NEJM case 26-1975; Fabinyi and Adams, 1979; Holmes et al., 1978; Klump, 1971; Mohanty et al., 1979).

Our patient presented with an unusually long clinical course of signs and symptoms that simulated multiple sclerosis. Although the explanation is not yet available, the possible mechanism for this in similar cases has been the subject of speculation (Adams and Wegner, 1947).

The pathologic findings reported in this case are unique; in that, the neurenteric cysts were multifocal, and were associated with a partial diplomyelia in the lumbo-sacral region, but no other developmental abnormalities.

\section{ACKNOWLEDGEMENTS}

We would like to thank Dr. W.P. McInnis who provided the clinical notes on the patient.

Histological sections were prepared by Mr. G. Helps. This paper was presented in part at the Canadian Congress of Laboratory Medicine, St. John's, Newfoundland, June, 1980

Manuscript was typed by Mrs. Linda Schettler.

\section{REFERENCES}

ADAMS, R.D., WEGNER, W. (1947), Congenital cyst of the spinal meninges as cause of intermittent compression of the spinal cord. Arch. Neurol. Psych. 58, 57-69.

BALE. P.M. (1973). A congenital intraspinal gastroenterogenous cyst in diastematomyelia. J. Neurol. Neurosurg. Psychiatry. $36,1011-1017$

Case records of the Massachusetts General Hospital (1975). Case 26-1975. N. Engl. J. Med. 293. 33-38.

DORSEY, J.F., TABRISKY, J., (1966). Intraspinal and mediastinal foregut cyst compressing the spinal cord: report of a case. J. Neurosurg. 24, 562-567.

FABINYI, G.C.A., ADAMS, J.E., (1979). High cervical spinal cord compression by an enterogenous cyst: case report. J. Neurosurg. 5I, 556-559.

HARRIMAN, D.G.F. (1958). An intraspinal enterogenous cyst. J. Pathol. 75, 413-419.

HOEFNAGEL, D. BENIRSCHKE, K. DUARTE, J., (1962). Teratomatous cysts within the vertebral canal: observations on the occurrence of sex chromatin. J. Neurol. Neurosurg. Psychiatry. 25, 159-164.

HOLMES G.L.. TRADER, S., IGNATIADIS, P., (1978). Intraspinal enterogenous cysts. Am. J. Dis. Child. 132, 906-908.
KLUMP, T.E., (197I). Neurenteric cyst in the cervical spinal canal of a 10-week-old boy. J. Neurosurg. 35, 472-476.

LAHA, R.K., HUESTIS, W.S., (1975). Intraspinal enterogenous cyst: delayed appearance following mediastinal cyst resection. Surg. Neurol. 3, 67-70.

LEVIN. P., ANTIN. S.P., (1964). Intraspinal neurenteric cyst in the cervical area. Neurology (Minneap). 14, 727-730.

MILLIS, R.R., HOLMES, A.E., (1973). Enterogenous cyst of the spinal cord with associated intestinal reduplication, vertebral anomolies, and a dorsal dermal sinus. $J$. Neurosurg. 38, 73-77.

MOHANTY. S., RAO. C.J.. SHUKLA. P.K.. et. al. (1979). Intradural enterogenous cyst. J. Neurol. Neurosurg. Psychiatry. 42, 419421.

ODAKE, G., YAMAKI, T., NARUSE, S., (1976). Neurenteric cyst with meningomyelocele: case report. J. Neurosurg. 45. 353-356.

PAGE, R.E. (1974). Intraspinal entergenous cyst associated with spondylolisthesis and spina bifida occulta. J. Bone Joint Surg. (Br). 56, 541-544.

PALMA. L., DI LOORENZO. N., (1976). Spinal endodermal cysts without associated vertebral or other congenital abnormalities. Acta. Neurochir. (Wien). 33, 283-300.

PILZ, P., FISCHBACH, R., BRENNEIS, M. (1977). Enterogene Cyste des Halmarkes mit Mucomyelie. Acta. Neuropathol. (Berl). 40. 277-278.

PIRAMOON, A.M.. ABBASSIOUN, K., (1974) Mediastinal enterogenic cyst with spinal cord compression. J. Pediatr. Surg. 9, 543545.

REWCASTLE, N.B., FRANCOEUR, J., (1964). Teratomatous cysts of the spinal canal. Arch. Neurol. 11, 91-99.

RHANEY, K., BARCLAY, C.P.T., (1959). Enterogenous cysts and congenital diverticula of the alimentary canal with abnormalities of the vertebral column and spinal cord. J. Pathol. Bacteriol. 77, 457-471.

ROSENBAUM. T.J., SOULE. E.H., ONOFRIO. B.M. (1978). Teratomatous cyst of the spinal canal: case report. J. Neurosurg. 49. 292-297.

SCOVILL.E, W.B., MANLAPAZ, J.S., OTIS, R.D.. CABIESES. F.. (1963), Intraspinal enterogenous cyst. J. Neurosurg. 20. 704706.

SILVERNAIL. W.I. Jr., BROWN. R.B., (1972). Intramedullary enterogenous cyst: case report. J. Neurosurg. 36, 235-238. 